\title{
Promotion of Banking Products and Services
}

\author{
Costinela FORTEA ${ }^{\star}$, Viorica IOAN ${ }^{\star \star}$
}

\begin{tabular}{l}
\hline \multicolumn{1}{c}{ A R T I C L E I N F O } \\
\hline Article history: \\
Accepted June 2019 \\
Available online August 2019 \\
\hline JEL Classification \\
G20, G21 \\
Keywords: \\
Banking products and services, \\
Promotion, banking marketing \\
\hline
\end{tabular}

A B S T R A C T

Banking marketing represents all the shares held by the bank in terms of investigating and market research, adjust products and services to market requirements owned or intends to enter, development, promotion and launch of new products in order to meet immediate objectives or the bank's perspective. Marketing of banking services also aims at increasing the knowledge of banking staff on some marketing concepts.

(C) 2019 EAI. All rights reserved.

\section{Introduction}

As the banking system has developed and customer requirements have become more complex, marketing of products and services has become a necessity. We can say that marketing consists of the following important activities: identifying the most profitable markets, identifying customer needs in these markets, developing products to meet these needs, promoting and managing products in order to achieve the objectives pursued.

\section{Promotion of banking products and services}

While the banking system has developed and customer requirements have become more complex, promotion of products and services has become a necessity. Marketing must gather relevant information from the environment, observe the needs at a certain point in time, anticipate future development, balance environmental influences, react in a timely manner, and adapt. So, as a bank to succeed, it is vital for it to market its products and services to continue its development. The bank will succeed only if potential customers know, buy and trust the products and services it offers.

According to Philip Kotler, the steps the banks have taken on the concept of marketing are the following:

* "Marketing means publicity , sales promotion and advertising" - in the first stage, banks have turned to advertisements and sales promotion to attract customers;

* In the second stage the banks took measures in terms of the atmosphere in the banks, making a friendly one to the liking of the clients;

* In the next step, banks began to innovate, creating new banking products and services, to exit the plurality;

* In the fourth stage in the evolution of the marketing concept was banking market positioning;

* As far as the last stage is concerned, banks have begun to research, plan and verify their marketing activities.

The main services offered to the individuals are:

* current accounts (in RON or currency);

* term deposit accounts;

\# deposit certificates;

\# loans in RON;

\# currency transactions;

* foreign exchange operations (payments and cash receipts, foreign exchange);

* payment card in RON;

* banking services related to issues of financial securities;

* safe deposit boxes.

The range of services offered to legal persons is the following:

* current accounts (in RON or currency); 
* term deposit accounts;

\# deposit certificates;

* buying / selling of currency;

* credits in lei and currencies for (for: necessity of production / supply, credit lines, development projects, etc);

* use of non-cash payment instruments;

* assessment and advice (for: assessing companies for liquidation, merger, privatization, valuation of assets, business plan, project financing, financial analysis);

* currency transactions;

* foreign currency transactions (cash payments / receipts, foreign exchange, issuing and confirmation of letters of credit, dispatch of commercial checks, factoring, flat-rate);

* bank guarantees;

* payment card in RON;

* bond portfolio management;

\# safe deposit boxes;

Marketing in the financial and banking institutions have a number of characteristics that are influenced on the one hand the nature of enterprise services for banks, on the other hand, the specific services:

* The statutory nature of the sector in which it operates, in most cases, the financial-banking institutions can not fully control their own offer or tariffs.

* Banking risks, their proper management can keep revenues in time, having the role of a shock absorber.

* Profitability of financial - banking products and services.

* Economic and sociological developments, with a particular impact on banking activity, in terms of profitability.

* Social responsibility of banks.

\# Absence of innovation protection.

* Level of knowledge of consumers of financial-banking products and services.

* The high degree of market segmentation.

* The existence of a time relationship between the client and the bank.

* Significant weight of non-performing accounts.

* The duality of bank-client relationships.

* Internal competition between different products and services offered by the same banking institution.

* Integration of the distribution channel.

* The existence of many prescriptors on the financial-banking market. Prescriptors represent various professional associations or companies in other areas of activity, such as those in the mobile telephony sector, which offer their customers the option to pay the bill using the bank card, which can significantly influence the decision of some consumers to purchase services and banking products.

Starting from the above, it can be argued that the banking institutions imprint a series of peculiarities to the marketing activity and at the same time provide additional explanations regarding the essential factors influencing, at the strategic and operational level, the relations with different categories of clients.

Table 1. Ranking of the first 35 banks on the Romanian financial banking market, depending on the assets held and the market share

\begin{tabular}{|c|c|c|c|c|c|}
\hline \multirow[t]{2}{*}{$\begin{array}{l}\text { No. } \\
\text { Crt }\end{array}$} & \multirow[t]{2}{*}{$\begin{array}{l}\text { Financial } \\
\text { institution }\end{array}$} & \multicolumn{2}{|c|}{ Total Assets (mil.lei) } & \multicolumn{2}{|c|}{ Market share } \\
\hline & & 2016 & 2017 & $2016(\%)$ & $2017(\%)$ \\
\hline 1 & BCR & 64.068 & 67.735 & 16,28 & 15,83 \\
\hline 2 & Banca Transilvania & 51.776 & 59.315 & 13,15 & 13,87 \\
\hline 3 & BRD-Société Générale & 50.658 & 53.491 & 12,87 & 12,5 \\
\hline 4 & Raiffeisen Bank & 33.420 & 37.549 & 8,49 & 8,78 \\
\hline 5 & UniCredit Bank & 32.687 & 36.085 & 8,30 & 8,44 \\
\hline 6 & CEC Bank & 28.195 & 33.657 & 7,16 & 7,87 \\
\hline 7 & ING Bank & 27.870 & 31.690 & 7,08 & 7,41 \\
\hline 8 & Alpha Bank & 14.733 & 15.638 & 3,74 & 3,66 \\
\hline 9 & Bancpost & 11.660 & 10.923 & 2,96 & 2,55 \\
\hline 10 & Garanti Bank & 8.960 & 9.985 & 2,28 & 2,33 \\
\hline 11 & OTP Bank & 8.215 & 9.151 & 2,09 & 2,14 \\
\hline 12 & Citibank & 6.815 & 6.717 & 1,73 & 1,57 \\
\hline 13 & Piraeus Bank & 6.572 & 6.447 & 1,67 & 1,51 \\
\hline
\end{tabular}




\begin{tabular}{llllll}
\hline 14 & Banca Românească & 6.383 & 6.253 & 1,62 & 1,46 \\
15 & Eximbank & 4.271 & 5.554 & 1,09 & 1,3 \\
16 & Credit Europe Bank & 4.292 & 4.685 & 1,09 & 1,1 \\
17 & Libra Internet Bank & 3.392 & 4.607 & 0,86 & 1,08 \\
18 & Intesa Sanpaolo & 4.088 & 4.054 & 1,04 & 0,95 \\
19 & Patria Bank & 1.138 & 3.645 & 0,29 & 0,85 \\
20 & BCR Locuințe & 3.109 & 2.921 & 0,79 & 0,68 \\
21 & Marfin Bank & 2.032 & 1.973 & 0,52 & 0,46 \\
22 & Idea Bank & 1.521 & 1.845 & 0,39 & 0,43 \\
23 & Bank of Cyprus & 1.624 & 1.624 & 0,41 & 0,41 \\
24 & Credit Agricole & 1.249 & 1.361 & 0,32 & 0,32 \\
25 & Pro Credit Bank & 1.383 & 1.311 & 0,35 & 0,31 \\
26 & Crditcoop & 1.111 & 1.215 & 0,28 & 0,28 \\
27 & Bank Leumi & 1.263 & 1.183 & 0,32 & 0,28 \\
28 & BNP Paribas & 1.065 & 992 & 0,27 & 0,23 \\
29 & Blom Bank & 799 & 794 & 0,2 & 0,19 \\
30 & Raiffeisen Locuințe & 745 & 625 & 0,19 & 0,15 \\
31 & TBI Bank & 608 & 622 & 0,15 & 0,14 \\
32 & Banca Feroviara & 646 & 574 & 0,16 & 0,13 \\
33 & Porsche Bank & 421 & 568 & 0,11 & 0,13 \\
34 & BRCI & 149 & 127 & 0,04 & 0,03 \\
35 & Alior Bank & 17 & 11 & 0 & 0 \\
& Total & 393.647 & 427.792 & 100 & 100 \\
\hline & & Source: National Bank of Romania & &
\end{tabular}

According to Table 1, at the level of 2017, BCR, owned by the Austrian Erste group, is ranked first with a market share of $15.83 \%$, dropping by $2.76 \%$ as compared to 2016 .

Transilvania Bank recorded a market share of $13.87 \%$, up with $5.47 \%$ compared to 2016. If BCR's market share dropped below the $20 \%$ threshold, its Austrian competitors from Raiffeisen reached 4th place, while UniCredit Bank ranked 5th.

The value of the assets managed by Raiffeisen Bank in Romania amounted to 37 million lei at the end of 2017 , and the market share of $8.78 \%$, increasing by $3.41 \%$ as compared to 2016 . BRD Société Générale is ranked 3 with a market share of $12.5 \%$, dropping with $2.87 \%$ as compared to 2016 . CEC Bank is ranked 6th by value of assets managed (33.657 million lei) market share of $7.87 \%$, up $9.91 \%$ over the previous year.

The local branch of the ING group ranks 7th in the ranking of banks, with a market share of $7.41 \%$, up 4.66\% over 2016. Alpha Bank ranks 8th, the assets being managed in 2017 by 15.638 million Lei, but with a market share of $3.66 \%$ decreasing by $2.13 \%$ compared to the previous year. Garanti Bank ranks 10 th by asset value, with a market share of $2.33 \%$ in 2017 , up $2.19 \%$ over 2016, followed by OTP Bank with a growing market share of $2,14 \%$ in 2017 , following banks with a market share below $2 \%$.

\subsection{Stages of the banking market segmentation process}

In the segmentation of the financial-banking market, potential customers can be discovered. The key stages of the segmentation process of the banking market are:

* Checking existing databases, in terms of quantity and quality;

* Identifying the target market;

* Defining segmentation criteria, these may be based on market characteristics.

Segmentation criteria for individual customers can be: geographic (regions, urban / rural environment, etc.), demographic (age, income, occupation, nationality, level of education, etc.), psychological (social class, personality, behavioral benefits (product benefits, product use, frequency of use, user status, loyalty, product attitude, etc.), banking (products held, account balances, deposits, etc.).

The segmentation criteria for legal entities are: the legal form, the object of activity, the number of employees, the turnover.

* Exploiting segmentation by informing people involved in activities, adapting the range of products and services to the expectations of each market segment, and developing the database.

Customers' needs change with changing circumstances. That is why, through customer satisfaction, there will be opportunities for banks to obtain profits from economic development.

The sales strategy must be based on three elements:

- Market knowledge, banks need to firmly adapt their supply of products and services to market requirements;

- Quality, the bank must provide a high standard, to remove its main competitors;

- Accessibility, banks need to organize their means in order to meet the needs of their clients in a short time. 


\subsection{Advertising in the promotion of banking products and services}

Banking advertising is a complex activity, including all acts of presenting a message about your product or service banking.

By advertising, commercial banks inform individuals and legal persons interested in the banking products and services that they can offer as widely as possible. The goal is to convince and determined people to buy their banking products and services. Advertisements are very diverse. Advertising through its communication power helps to transform consumer demand into effective purchasing. The purpose of banking advertising is to stimulate the demand for banking products and services.

The marketing activity of banks it helps to increase investor confidence. So, through marketing can be anticipated financing decisions, resource acquisition, investment decisions, using customer feedback systems to help improve the image of the bank. Commercial banks, through marketing activities, influence individuals and businesses to make optimal decisions.

Advertising ensures market gain within commercial banks, promotes the achievement of the objective of a bank's commercial function by: finding outlets for bank products, increasing the weight of a bank for a certain duration, creating the conditions for setting up offices to consolidating the acquired position and ensuring entry into other markets.

\section{Marketing strategies in the financial and accounting field}

From the point of view of financial banking marketing, the main objectives are:

- satisfying customers at the same time as achieving the bank's objectives;

- profitability, being a balance between customer satisfaction and bank profits;

- social responsibility, banks need to be aware of the environment in which they act and their role in society;

Marketing strategies are a component of marketing policies, whereby banks set out how to achieve their goals. The banking market, like any market, is marked by the existence of competition. Thus, Michael Porter's model with the five competitive forces can be outlined at the market level, namely: customers, existing competitors, new entrants to the market, suppliers and substitutes.

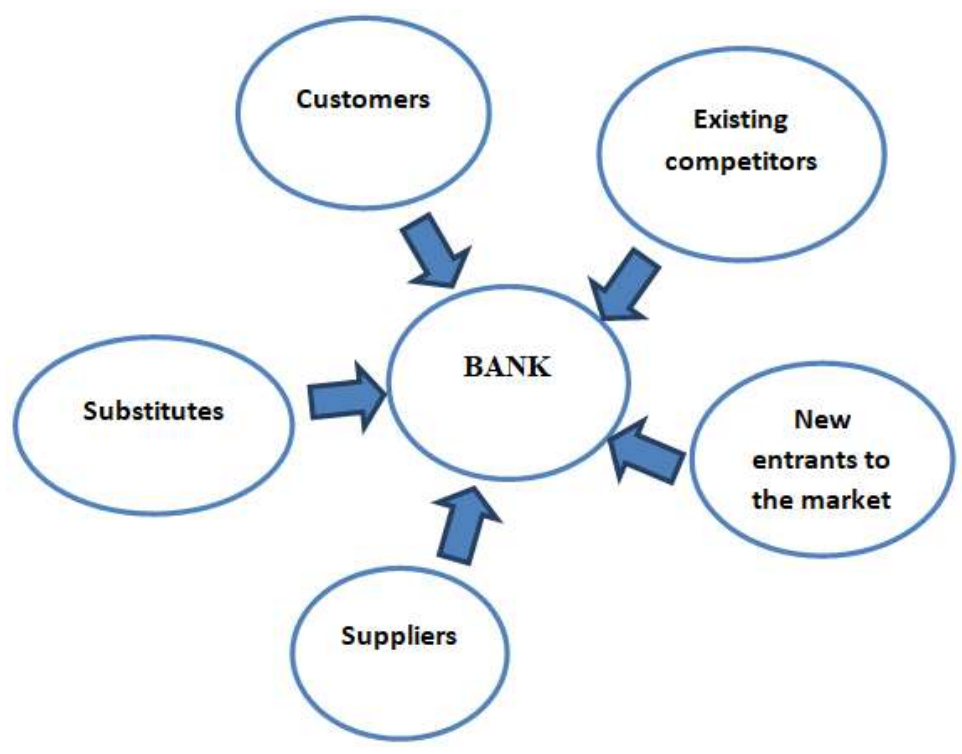

Figure 1- Porter Model

Thus, the activity of banking marketing becomes impossible to achieve without using as a management tool, the market strategies.

Four categories of market strategies are distinguished in this sector, depending on the position of the institutions within it, namely: leader, challenger, pursuer, specialist.

An effective marketing strategy is based on customer and competition. The elements behind the success of the maketing strategy relate to both customer knowledge and competition.

\section{Conclusion}

The main objectives of banking institutions in terms of marketing activity are: customer satisfaction while attaining the Bank's objectives, profitability and social responsibility. To achieve this, banks need to develop and implement a range of marketing strategies. 
Wording strategic methods is based on the analysis of the market, the sector in which it operates, the competitors, as well as the need to identify the sustainable competitive advantage and the needs of the clients.

\section{References}

1. Aacker A.D. - Strategic Market Management, John Wiley \& Sons, NewYork, 2004.

2. Adam C. - Marketing financiar - bancar, Editura Mirton, Timișoara, 2007.

3. Badoc M.- Marketing management pur les societes financieres (banques. Societes d, assurances), Edition d'Organisation, Paris, 1995

4. Badoc M. - E-marketing de la banque et de l'assurance, Editions d'Organisations, Paris, 1999.

5. Basno C., Dardac N. - Management bancar, Editura Economică, Bucureşti, 2000.

6. Dănilă D., Berea A.O. - Managementul bancar. Fundamente și orientări, Editura Economică, București, 2000.

7. Dătculescu P. - Cercetări de marketing - Cum pătrunzi în mintea consumatorului, cum măsori și cum analizezi informația, Editura Brandbuilders Grup, București, 2006

8. Dedu V., Enciu A., Ghencea S. - Produse si servicii bancare, Editura ASE, Bucuresti, 2008.

9. Gheorghe G., Lupasc I, A growing challenge for online business, International Conference Risk in Contemporary Economy, 2017, http://lumenpublishing.com/proceedings/.../rec-november-2017/

10. Kotler Ph.- Managementul marketingului,Analiză, planifiare, implementare, contol, Editura Teora, București 1997

11. Kotler Ph., Armstrong G., Saunders J., Wong V. - Principiile Marketingului, Editura Teora, București, 1998.

12. Kotler Ph. - Principiile marketingului, Editia a III-a, Editura Teora, Bucuresti, 2004.

13. Lupasc I., Finante si elemente de modelare financiara, Editura Europlus, 2013.

14. Odobescu E. - Marketingul bancar modern, Editura Sigma, București, 2003.

15. Odobescu E., Poantă D. - Relațiile băncilor cu clienții (Elemente de marketing), Editura Sigma, Bucureşti, 2003.

16. Păcurariu Gh., Curețeanu R., Bâra E. - Marketingul instituțiilor financiar - bancare, Editura UniversităNii „Aurel Vlaicu”, Arad, 2006.

17. Popescu J. - Marketingul serviciilor financiar - bancare, Editura Sitech, Craiova, 2009

18. Trencă I. - Metode și tehnici bancare, Editura Casa Cărții de Ştiință, Cluj-Napoca, 2002

19. Văcărel I. (coord.) - Finanțe publice, Editura Didactică și Pedagogică, București, 1992.

20. Voicu C. N. - Marketing financiar - bancar, Editura Universității Babeș - Bolyai, Cluj-Napoca, 2008

21. Vonea A.I., Vonea R.L. - Marketingul bancar, Editura Abaddaba, Oradea, 2002.

22. Banca Națională a României www.bnr.ro 